STUDIA PRAWNO-EKONOMICZNE, T. CXVI, 2020

PL ISSN 0081-6841; e-ISSN 2450-8179 s. 117-134

https://doi.org/10.26485/SPE/2020/116/7

\title{
Magdalena SKIBIŃSKA*
}

iD https://orcid.org/0000-0003-1676-1157

\section{WYBRANE ZAGADNIENIA DOTYCZACE UMOWY DOWODOWEJ W POSTĘPOWANIU ODRĘBNYM W SPRAWACH GOSPODARCZYCH}

\begin{abstract}
Abstrakt
Przedmiot badań: Przedmiotem badań jest wprowadzona nowelizacją z dnia 4.07.2019 r. do Kodeksu postępowania cywilnego instytucja umów dowodowych w postępowaniu odrębnym w sprawach gospodarczych.

Cel badawczy: Celem artykułu jest nie tylko zbadanie zakresu zastosowania regulacji art. $458^{9}$ k.p.c. i dopuszczalnych wyłączeń w umowie dowodowej, ale także określenie skutków zawarcia umowy dowodowej oraz potencjalnych zalet i wad, jakie mogą się wiązać z zawarciem takiej umowy z perspektywy celu nowelizacji (jakim jest usprawnienie postępowania) oraz pewności obrotu gospodarczego. Metoda badawcza: W analizie wykorzystano metodę dogmatycznoprawną.

Wyniki: Przeprowadzone rozważania prowadzą do wniosku, że wprowadzenie umów dowodowych może pod pewnymi warunkami prowadzić do usprawnienia postępowania cywilnego. Jednakże w sytuacji konieczności badania skuteczności i ważności umowy dowodowej korzyść ta może być iluzoryczna. Regulacja ta może także skutkować nadużyciem pozycji ekonomicznej między dużymi a małymi przedsiębiorcami.
\end{abstract}

Słowa kluczowe: nowelizacja Kodeksu postępowania cywilnego, szybkość postępowania, pozycja małych i dużych przedsiębiorców.

\section{Wstęp}

Ustawą z dnia 4 lipca 2019 r. o zmianie ustawy - Kodeks postępowania cywilnego oraz niektórych innych ustaw ${ }^{1}$ ustawodawca przywrócił postępowanie odrębne w sprawach gospodarczych po ponad siedmiu latach jego nieobowiązywania ${ }^{2}$.

* Dr, Uniwersytet Zielonogórski, Wydział Prawa i Administracji, Katedra Prawa Cywilnego, Postępowania Cywilnego oraz Komparatystyki Prawa Prywatnego; e-mail: mskibinska@ uz.zgora.pl

1 Dz.U. z 2019 r., poz. 1469.

2 Pierwotnie postępowanie to wprowadzone zostało do k.p.c. ustawą z dnia 24 października 1989 r. o rozpoznawaniu przez sądy spraw cywilnych (Dz.U. z 1989 r., nr 33, poz. 175 ze zm.) 
Spośród wprowadzonych w tym zakresie regulacji przepis art. $458^{9}$ Kodeksu postępowania cywilnego ${ }^{3}$ poświęcony został $\mathrm{w}$ całości kwestii umowy dowodowej. Zagadnienie to wzbudza żywe zainteresowanie zarówno praktyków, jak i teoretyków prawa. Tych ostatnich dzieli przede wszystkim spór co do charakteru prawnego umowy dowodowej jako umowy procesowej oraz interesuje kwestia prywatyzacji prawa dowodowego czy szerzej prawa publicznego w wyniku ich wprowadzenia ${ }^{4}$. Zagadnienia te, choć ciekawe, są na tyle obszerne, że nie sposób ich omówić, choćby skrótowo, w niniejszym opracowaniu. Wynika to m.in. z konieczności szerszego spojrzenia na kwestię umów procesowych w postępowaniu cywilnym. Dlatego przedmiotem dalszych rozważań będą jedynie kwestie praktyczne związane m.in. ze sposobem formułowania tego typów umów, zakresem wyłączeń dopuszczalnych w umowie dowodowej i potencjalnymi zagrożeniami, jakie mogą się wiązać z zawarciem takiej umowy.

\section{Zakres zastosowania regulacji art. $458^{9}$ k.p.c. i dopuszczalnych wyłączeń w umowie dowodowej}

Wprowadzając regulację art. $458^{9}$ do kodeksu, ustawodawca jednoznacznie przesądził dopuszczalność zawierania umów dowodowych w sądowym postępowaniu cywilnym ${ }^{5}$. Jednocześnie umiejscowienie tej regulacji w przepisach

i obowiązywało do dnia 3 maja 2012 r., tj. do dnia wejścia w życie ustawy z dnia 16 września 2011 r. o zmianie ustawy - Kodeks postępowania cywilnego oraz niektórych innych ustaw (Dz.U. z 2011 r., nr 233, poz. 1381).

3 Ustawa z dnia 16 listopada 1964 r. Kodeks postępowania cywilnego (t.j. Dz.U. z 2019 r., poz. 1460 ze zm.), dalej k.p.c.

4 Zob. J. Gudowski, w: T. Zembrzuski (red.), Kodeks postępowania cywilnego. Koszty sądowe w sprawach cywilnych. Dochodzenie roszczeń w postępowaniu grupowym. Przepisy przejściowe. Komentarz do zmian, Tom II, Wolters Kluwer, Warszawa 2019, s. 1131; L. Blaszczak, Umowa dowodowa jako przyktad nowej instytucji w Kodeksie postępowania cywilnego (art. $458^{9}$ k.p.c.), Palestra 2019/11-12, s. 134-148; R. Kulski, Odrębności postępowania w sprawach gospodarczych, MoP 2019/21, s. 1171.

5 Do czasu wprowadzenia omawianej nowelizacji brak było jednolitego stanowiska w tej kwestii. Za możliwością taką opowiadali się L. Blaszczak, w: L. Błaszczak, K. Markiewicz (red.), Dowody i postepowanie dowodowe $w$ sprawach cywilnych. Komentarz praktyczny z orzecznictwem. Wzory czynności sądowych i procesowych, C.H. Beck, Warszawa 2015, s. 89-90; L. Blaszczak, Problematyka umów dowodowych w sądowym postępowaniu cywilnym ze szczególnym uwzględnieniem dowodu z opinii biegłego ad hoc, w: L. Błaszczak, K. Markiewicz (red.), Rola biegłego w postepowaniach sadowych, Presscom, Wrocław 2016, s. 18-46; A. Borys, Umowy dowodowe i ich praktyczne wykorzystanie w perspektywie projektowanych zmian kodeksu postępowania cywilnego, w: G. Jędrejek, S. Kotas, F. Manikowski (red.), 
o postępowaniu odrębnym w sprawach gospodarczych powoduje, że możliwość taka została ograniczona jedynie do tego postępowania ${ }^{6}$. Tym samym zawarcie umowy dowodowej w innych sprawach niż gospodarcze ${ }^{7}$ jest niedopuszczalne.

Ustawodawca, dokonując omawianej nowelizacji, przyjął jednocześnie definicję legalną umowy. Na jej podstawie wskazany zostanie zakres zastosowania tej instytucji i dopuszczalnych wyłączeń w umowie dowodowej. W myśl $§ 1$ omawianej normy strony mogą się umówić o wyłączenie określonych dowodów $\mathrm{w}$ postępowaniu $\mathrm{w}$ sprawie $\mathrm{z}$ określonego stosunku prawnego powstałego na podstawie umowy (umowa dowodowa). Na pojęcie to składają się następujące elementy:

1) konsensus stron co do zawarcia umowy dowodowej,

2) sprawa musi wynikać z określonego stosunku prawnego,

3) stosunek ten musi powstać na podstawie umowy,

4) w drodze zawarcia umowy dowodowej dochodzi do wyłączenia określonych dowodów w postępowaniu cywilnym.

Postepowanie cywilne - wprowadzone i projektowane zmiany 2019, Wolters Kluwer, Warszawa 2019, s. 145-147; we wcześniejszej literaturze również M. Mikuszewski, Dopuszczalność umów regulujacych sposób prowadzenia dowodów w procesie, Ruch Prawniczy, Ekonomiczny i Socjologiczny 1939/3, s. 226; wprowadzenie regulacji dotyczącej umów dowodowych postulował również R. Kulski, Umowy procesowe w postępowaniu cywilnym (rozważania prawnoporównawcze), w: I. Ratusińska (red.), Czterdziestolecie Kodeksu postępowania cywilnego. Zjazd Katedr Postępowania Cywilnego w Zakopanem (7.-9.10.2005), Zakamycze, Warszawa 2006, s. 97; R. Kulski, Umowy procesowe w postępowaniu cywilnym, Zakamycze, Kraków 2006, s. 311-312. Przeciwko takiemu poglądowi wypowiadali się np. A. Skąpski, Ograniczenia dowodzenia $w$ procesie cywilnym, PWN, Warszawa-Kraków 1981, s. 31; H. Dolecki, Ciężar dowodu w polskim procesie cywilnym, Wydawnictwa Prawnicze PWN, Warszawa 1998, s. 75; K. Piasecki, System dowodów i postępowanie dowodowe w sprawach cywilnych, LexisNexis, Warszawa 2010, s. 262; K. Knoppek, Recenzja ksiażki „Dowody w postępowaniu cywilnym”, E. Błaszczak, K. Markiewicz, E. Rudkowska-Ząbczyk (red.), C.H. Beck, Warszawa 2010, s. XLIV +672 , nr 2, s. 162. Bezsporna była natomiast dopuszczalność zawarcia umowy dowodowej w postępowaniu arbitrażowym w świetle sformułowania art. 1184 § 1 k.p.c., zob. np. R. Morek, I. Szmit, Uwagi o dopuszczalności i skuteczności umów dowodowych w postępowaniach cywilnych i arbitrażowych, w: J. Poczobut, A. Wiśniewski (red.), Prawo prywatne i arbitraż. Księga jubileuszowa dedykowana doktorowi Maciejowi Tomaszewskiemu, Sąd Arbitrażowy przy Krajowej Izbie Gospodarczej w Warszawie, Warszawa 2016, s. 216-223.

6 M. Skibińska, Dowód z zeznań świadka w świetle projektu ustawy o zmianie ustawy - Kodeks postępowania cywilnego oraz niektórych innych ustaw z 8.01.2019 r., w: G. Jędrejek, S. Kotas, F. Manikowski (red.), Postepowanie cywilne - wprowadzone i projektowane zmiany 2019, Wolters Kluwer, Warszawa 2019, s. 136.

7 Odnośnie do tego pojęcia zob. art. $458^{2}$ k.p.c. 
Pierwsza ze wskazanych kwestii eliminuje możliwość jednostronnego wyłączenia określonych dowodów w postępowaniu gospodarczym, a tym samym również (przynajmniej teoretycznie) narzucenia takiego rozwiązania przez jedną ze stron stosunku prawnego drugiej bez jej zgody. Mieści się to zresztą już w samym pojęciu „umowa”, co oznacza co najmniej dwustronne porozumienie. Drugi wymóg wyklucza możliwość zawarcia ogólnej umowy dowodowej, u podstaw której leżą wszystkie stosunki prawne łączące strony podstępowania gospodarczego. Stosunek ten musi być konkretnie i jednoznacznie oznaczony. Trzeci warunek oznacza, że stosunek prawny, którego sprawa dotyczy, nie może powstać np. w drodze czynów niedozwolonych ${ }^{8}$, jednostronnych czynności prawnych, z prowadzenia cudzych spraw bez zlecenia czy bezpodstawnego wzbogacenia. Stosunek ten musi wynikać z umowy, niezależnie od tego, czy jest to umowa nazwana (np. umowa sprzedaży, agencyjna, leasingu), czy nienazwana (np. umowa franczyzy czy factoringu). Chodzi przy tym o umowę prawa cywilnego materialnego. Natomiast jeśli chodzi o rodzaj powództwa, w którym może być wykorzystana, to należy uznać, że nie ma tu jakichkolwiek ograniczeń. Może być to więc zarówno powództwo o świadczenie, powództwo o ukształtowanie prawa lub stosunku prawnego, jak również powództwo o ustalenie prawa lub stosunku prawnego. Czwarty element definicji pozwala na wyłączenie w umowie dowodowej jakiegokolwiek środka dowodowego, zarówno nazwanego (zostały uregulowane w art. $243^{1}-308$ k.p.c.), jak i nienazwanego (których przeprowadzenie w postępowaniu cywilnym odbywa się na zasadach określonych w art. 309 k.p.c.). Może tu więc chodzić przykładowo o wyłączenie dowodu z zeznań świadka ${ }^{9}$ (jednego określonego lub ogólnie wszystkich) czy przesłuchania strony, dowodu z dokumentu (konkretnie wskazanego lub też wszystkich - prywatnych, urzędowych lub jednych i drugich), opinii biegłego (jednego imiennie wymienionego, określonej specjalności, kilku specjalizacji, wszystkich), możliwości przeprowadzenia eksperymentu procesowego. Ponadto w umowie takiej można również wykluczyć więcej niż jeden środek dowodowy, ponieważ ustawodawca nie zawarł jakichkolwiek ograniczeń w tym zakresie.

Kwestią wymagającą rozstrzygnięcia jest natomiast możliwość wyłączenia w umowie dowodowej wszystkich środków dowodowych bez ich sprecyzowania. Przeciwko takiej dopuszczalności może przemawiać wykładnia językowa użytego w art. $458^{9} \S 1$ k.p.c. terminu „określonych”. Pojęcie to oznacza, że

Uzasadnienie, s. 107.

9 Zob. M. Skibińska, op. cit., s. 136. 
chodzi o konkretnie oznaczone dowody ${ }^{10}$. Tym samym należy stwierdzić, że zawarcie umowy dowodowej dotyczącej wszystkich środków dowodowych bez ich sprecyzowania jest niedopuszczalne, a umowę taką należałoby uznać za bezskuteczną. Możliwe jest natomiast wyłączenie każdego środka dowodowego (nazwanego lub nienazwanego), gdyż ustawodawca nie przewiduje żadnych restrykcji odnośnie do tej kwestii. Nie jest jednocześnie konieczne wskazanie konkretnie o zeznania jakiego świadka chodzi ani też jaki specjalista zostanie wyłączony od sporządzenia opinii, choć nie jest także wykluczone wyłączenie imienne świadków lub biegłych (np. dowodu z zeznań świadka Jana Kowalskiego lub dowodu z opinii biegłego Jacka Nowaka), lub dowodów z opinii biegłego określonych specjalności (np. dowodu z opinii biegłego grafologa). Podobnie można wyłączyć możliwość powołania się ogólnie na dowody z dokumentów, ale również tylko określonych dokumentów (np. dokumentów prywatnych albo urzędowych czy też umowy zawartej pomiędzy stronami nr 112/2019 z dnia 15.10.2019 r.). Innymi słowy wyłączenie może dotyczyć ogólnie poszczególnych środków dowodowych albo zindywidualizowanego dowodu. Szczególną zaletę może stanowić wyłączenie tych dowodów, które obejmują tajemnicę przedsiębiorstwa ${ }^{11}$. Wymienienie $\mathrm{w}$ umowie dowodowej sprecyzowanych środków dowodowych, które jednocześnie $\mathrm{w}$ danej sprawie stanowią wszystkie środki dowodowe, z których strony mogą de facto skorzystać, prowadzi do faktycznego wyłączenia wszystkich środków dowodowych w tym postępowaniu ${ }^{12}$. Ponieważ jednak katalog środków dowodowych jest otwarty (zob. art. 309 k.p.c.), to uznać należy, że w praktyce zawsze będzie istniała - choćby tylko potencjalnie - możliwość skorzystania przez stronę z dowodu niewyłączonego wyraźnie przez strony w umowie dowodowej. Jeśli in concreto wyłączone będzie przeprowadzenie postępowania dowodowego w sprawie, sąd orzeknie, stosując przepis art. $458^{9}$ $\S 7$ k.p.c. Jest to ryzyko, jakie ponoszą strony decydujące się na zawarcie tego typu umowy dowodowej w imię przyspieszenia rozpoznania sprawy. Oczywiste jest przy tym, że dość często takie umowy będą prowadziły do postawienia w gorszym położeniu przynajmniej jednej ze stron procesu.

10 Według Słownika języka polskiego PWN słowo ‘określony’ oznacza „sprecyzowany, wiadomy, pewny", zob. https://sjp.pwn.pl/szukaj/okre\%C5\%9Blony.html; stan na 22.08.2020 r.

11 Zwraca na to słusznie uwagę A. Borys, op. cit., s. 153.

12 J. Gudowski, op. cit., s. 1134-1135 wskazuje, że kierując się zwłaszcza wykładnią prokonstytucyjną, trzeba przyjąć, że zwrot „określone dowody” nie pozwala na wyłączenie przez strony wszystkich możliwych dowodów. Zdaniem tego autora byłoby to bowiem w istocie równoznaczne z wyłączeniem prawa do sądu w ujęciu i rozumieniu art. 45 Konstytucji RP. Umowa dowodowa zawierająca takie wyłączenie byłaby zatem nieważna. 
Z punktu widzenia podziału umów dowodowych na zawężające i rozszerzające ${ }^{13}$ ustawodawca w świetle art. $458^{9} \S 1$ k.p.c. przewidział jedynie umowę zawężającą możliwość dowodzenia, a konkretnie powołania się w postępowaniu gospodarczym na określone środki dowodowe. Nie jest tym samym dopuszczalne zawarcie umowy rozszerzającej ${ }^{14}$, co do przedmiotu dowodu, określającej twierdzenia o faktach, które strony mają udowodnić w toku postępowania lub uznają za udowodnione, co do rozkładu ciężaru dowodu oraz regulującej sposób przeprowadzania dowodu ${ }^{15}$, które to umowy również zaliczane są do umów dowodowych. W szczególności, w kontekście innych odrębności postępowania dowodowego w postępowaniu gospodarczym, niedopuszczalne byłoby zawarcie umowy wyłączającej subsydiarny charakter dowodu z zeznań świadka (art. $458^{10}$ k.p.c.) czy umowy przewidującej możliwość dowodzenia faktów, o których mowa w art. $458^{11}$ k.p.c. za pomocą innych środków dowodowych niż dowód z dokumentu w rozumieniu art. $77^{3}$ k.c. ${ }^{16}$ Wynika to po pierwsze $\mathrm{z}$ charakteru tych norm jako bezwzględnie obowiązujących (iuris cogentis), a po drugie z przyjęcia, że zarówno jedna, jak i druga umowa miałyby charakter rozszerzający w stosunku do regulacji kodeksowych, czego aktualnie nie przewiduje przepis dotyczący umowy dowodowej. Zasadniczo strony nie mogą także wyłączyć określonych dowodów we wszystkich postępowaniach gospodarczych między nimi, ale skutki jednej umowy dowodowej mogą się rozciągać na kilka odrębnych postępowań sądowych dotyczących różnych sporów wynikłych w związku z tym samym łączącym strony umownym stosunkiem prawnym.

\section{Skutki zawarcia umowy dowodowej}

Skutek zawarcia umowy dowodowej polega na niedopuszczalności skorzystania $\mathrm{z}$ wyłączonego w umowie środka dowodowego, choćby strona wniosła o jego przeprowadzenie ${ }^{17}$. W razie zaistnienia tej ostatniej sytuacji sąd powinien pomi-

13 W literaturze polskiej na podział ten wskazywał jeszcze w literaturze przedwojennej M. Mikuszewski, op. cit., s. 226-227.

14 Umowa taka mogłaby zresztą przeczyć zakładanemu celowi przyspieszenia postępowania, zob. szerzej A. Borys, op. cit., s. 149.

15 Na różne rodzaje umów dowodowych wskazują R. Kulski, Umowy procesowe w postępowaniu cywilnym (rozważania prawnoporównawcze)..., s. 73; R. Kulski, Umowy procesowe w postępowaniu cywilnym, Zakamycze, Kraków 2006, s. 2; a za nim R. Morek, I. Szmit, op. cit., s. 214-215. Inne jeszcze rodzaje umów dowodowych wyróżnił M. Mikuszewski, op. cit., s. 226-227.

16 Ustawa z dnia 23 kwietnia 1964 r. Kodeks cywilny (t.j. Dz.U. z 2019 r., poz. 1145 ze zm.), dalej k.c.

17 Odrębnym problemem jest natomiast możliwość zmiany umowy dowodowej w ten sposób, że strony zgodzą się na przeprowadzenie dowodu, który wcześniej był wyłączony. Należy 
nąć dowód wyłączony umową dowodową zgodnie z art. $235^{2} \S 1$ pkt 1 k.p.c. ${ }^{18}$ Ponadto sąd nie jest uprawniony do przeprowadzenia takiego dowodu również $\mathrm{z}$ urzędu. Ten ostatni skutek został unormowany w art. $458^{9} \S 6$ k.p.c. W myśl tego przepisu sąd nie dopuści z urzędu dowodu wyłączonego umową dowodową ${ }^{19}$. Od reguły tej ustawodawca nie przewidział w ostatecznym brzmieniu przepisów żadnych wyjątków. Nieprzeprowadzenie dowodów w tym zakresie nie oznacza jednak niemożliwości ustalenia faktów, które strona chciała wyłączonymi dowodami wykazać. W myśl § 7 omawianego przepisu fakty takie sąd może ustalić na podstawie twierdzeń stron, biorąc pod rozwagę całokształt okoliczności sprawy ${ }^{20}$. Jeżeli ustalenia wymaga rozmiar należnego świadczenia, przepis art. 322 stosuje się odpowiednio ${ }^{21}$. Tuż przed wprowadzeniem omawianego przepisu wskazywano w doktrynie, że konieczność zastosowania art. $458^{9} \S 7$ k.p.c. uzasadnia wprowadzenie do postępowania gospodarczego składu ławniczego, przy czym ławnikiem mógłby być tylko przedsiębiorca $\mathrm{z}$ odpowiednio dużym doświadczeniem, co mogłoby prowadzić niejako do zastąpienia dowodu z opinii biegłego i wprowadzenia elementu wiedzy specjalistycznej do postępowania wówczas, gdy dowód taki byłby objęty wyłączeniem w umowie dowodowej ${ }^{22}$. Argument

pamiętać, że zgłoszenie wniosku dowodowego o przeprowadzenie takiego dowodu powinno jednak nastąpić w terminach zakreślonych w art. $458^{5}$ k.p.c.

18 Po omawianej nowelizacji przepisów k.p.c. nieprawidłowe jest posługiwanie się pojęciem oddalenia wniosku dowodowego, dowód taki należy pominąć - zgodnie z terminologią zawartą w art. 235². Por. T. Szancilo, w: T. Szancilo (red.), Kodeks postępowania cywilnego. Komentarz. Art. 1-505 $5^{39}$. Tom I, C.H. Beck, Warszawa 2019, Legalis 2019, Komentarz do art. $458^{9}$.

19 Przepis ten stanowi odstępstwo od regulacji zawartej w art. 232 zd. 2 k.p.c. Trzeba jednak zwrócić uwagę, że jeszcze przed wprowadzeniem omawianej regulacji wskazywane były argumenty przeciwko wyłączeniu możliwości dopuszczenia przez sąd z urzędu dowodów objętych porozumieniem dowodowym, jeśli sąd podjąłby wątpliwości m.in. co do bezwzględnej nieważności czynności prawnej, prowadzenia przez strony fikcyjnego procesu lub gdy w procesie występuje strona nieporadna działająca bez adwokata czy radcy prawnego - tak Ł. Błaszczak, op. cit., s. 41. Nie wiadomo przy tym, czy ustalenie to ma się odbyć z zastosowaniem reguł art. 229 i 230 k.p.c., czy także z ich pominięciem. Jeśli z ich uwzględnieniem, to słusznie wskazuje T. Szanciło, że norma ta jest zbędna, Kodeks..., Komentarz do art. $458^{9}$.

21 Negatywnie odnośnie do tego rozwiązania W. Głodowski, Odrębności w postępowaniu dowodowym w postępowaniu w sprawach gospodarczych, w: M. Skibińska (red.), Aktualne zagadnienia postępowania dowodowego i środków dowodowych w postępowaniu cywilnym, Acta Iuridica Lebusana, vol. 14, Oficyna Wydawnicza Uniwersytetu Zielonogórskiego, Zielona Góra 2020, s. 26, wskazując, że ustalenie tej kwestii będzie się opierało na arbitralnej decyzji sądu oraz T. Szancilo (Kodeks..., Komentarz do art. $458^{9}$ ) słusznie wskazujący, że żaden przepis k.p.c. nie wyłącza stosowania art. $322 \mathrm{w}$ postępowaniu gospodarczym w związku z tym norma art. $458^{9}$ $\S 7$ zd. 2 k.p.c. jest zbędna.

22 A. Borys, op. cit., s. 153. 
ten nie zasługuje jednak na akceptację. Istnienie takiego rozwiązania zwiększyłoby koszty prowadzonych postępowań, a tylko w niewielkim stopniu mogłoby ewentualnie wpłynąć na sprawiedliwość wydawanych wyroków.

Problemem, który może się pojawić na tym tle, może być natomiast moment podniesienia przez stronę zarzutu istnienia umowy dowodowej dla zaistnienia powyższych skutków. Rozważania w tym względzie należy zacząć od ogólnego stwierdzenia, że umowa dowodowa może być zawarta przed powstaniem sporu lub już po jego powstaniu, przed wszczęciem postępowania sądowego lub w trakcie jego trwania. Ten ostatni wniosek wypływa $z$ treści art. $458^{9} \S 5$ k.p.c. Zgodnie $\mathrm{z}$ jego brzmieniem objęcie umową dowodową dowodu przeprowadzonego przed sądem przed jej zawarciem nie pozbawia go mocy dowodowej. Dotyczy to również dowodu przeprowadzonego $\mathrm{w}$ ramach zabezpieczenia dowodu. W praktyce kłopotliwa może być jednak inna sytuacja, tj. taka, gdy do zawarcia umowy dowodowej wprawdzie doszło przed wszczęciem postępowania sądowego albo choćby przed przeprowadzeniem wyłączonego w umowie dowodu, ale okoliczność ta została podniesiona już po przeprowadzeniu dowodu objętego wyłączeniem. Oczywistym jest, że wówczas niedopuszczalne byłoby pominięcie takiego dowodu, gdyż w istocie został on już przeprowadzony. W takim przypadku uznać należy, że powoływanie się na umowę dowodową w celu np. zdyskredytowania niekorzystnych zeznań świadka nie powinno wywoływać skutków dla już przeprowadzonego postępowania dowodowego ${ }^{23}$. Podobnie - na co wskazuje prawodawca, uzasadniając wprowadzenie regulacji art. $458 \S 5$ k.p.c. - można przyjąć, że „skoro treść takiego dowodu dotarła już do świadomości sędziego i wpłynęła na jego pogląd na sprawę, to uważanie takiego dowodu za niebyły byłoby fikcją. Należy więc przewidzieć, że nie pozbawia go to mocy dowodowej" ${ }^{24}$. Przyjęcie odmiennej wykładni tego przepisu prowadziłoby do dowolnego manipulowania przez strony umową dowodową w zależności od tego, czy dany dowód jest albo będzie korzystny lub nie. Zaburzałoby to również dynamikę postępowania i narażałoby sąd na dokonywanie czynności procesowych, których następnie wynik nie mógłby zostać wykorzystany przy ustaleniu podstawy faktycznej rozstrzygnięcia. Poza tym tak samo jak zawarcie umowy dowodowej jest przejawem dyspozycyjności formalnej stron tej umowy, tak samo podniesienie tego faktu leży w gestii stron tego postępowania. W związku z tym dopuszczalne jest przeprowadzenie postępowania dowodowego przez sąd w zakresie objętym umową dowodową i oparcie się na wynikach tego postępowania w orzeczeniu

Tak również ibidem, s. 151.

24 Uzasadnienie, s. 107. 
merytorycznie rozstrzygającym sprawę, jeśli strony nie podniosły zarzutu procesowego zawarcia takiej umowy. Co więcej niemożliwe byłoby powoływanie się na ten zarzut dopiero przed sądem drugiej instancji w celu podważenia zapadłego przed sądem pierwszej instancji wyroku. Problem ten dotyczy oczywiście sytuacji, gdy umowa dowodowa została zawarta jako odrębna umowa. W przypadku, gdy jest ona częścią umowy regulującej podstawowy stosunek prawny łączący strony i jest załączona do akt sprawy, sąd powinien wziąć fakt zawarcia umowy dowodowej pod uwagę z urzędu i pominąć wymienione w niej dowody ${ }^{25}$.

W końcu za koniecznością wzięcia przez sąd pod uwagę przeprowadzonego już dowodu, choćby strona podniosła zarzut zawarcia umowy dowodowej, przemawia fakt, że ustawodawca nie zdecydował się na wprowadzenie podobnych regulacji procesowych, które obowiązują przy innych umowach procesowych, a które ustanawiają termin do zgłoszenia zarzutu zawarcia takiej umowy (art. 200 $\S 1^{2} \mathrm{zd}$. 2 - w odniesieniu do umowy prorogacyjnej, art. $202^{1}$ - w zakresie umowy o mediację, art. $1165 \S 1$ - dotyczący zgłoszenia zarzutu zawarcia zapisu na sąd polubowny). Brak takiej regulacji wynika z braku cezury czasowej, do której możliwe jest zawarcie umowy dowodowej. Jak wskazano, umowę można zawrzeć także w toku całego postępowania. Również zgłoszenie zarzutu zawarcia umowy dowodowej może nastąpić na różnych etapach postępowania. Jednakże skutki zawarcia umowy dowodowej zachodzić będą dopiero od chwili, w której sąd miał okazję się o tym fakcie dowiedzieć. Nawet jeśli w chwili przeprowadzenia dowodu umowa już istniała, to $\mathrm{w}$ granicach rozporządzalności swoim prawem mieści się zgłoszenie tego faktu w sądzie. Dlatego strony - pomimo zawarcia umowy dowodowej - mogą podnieść ten zarzut lub nie. Może to uczynić zarówno powód, jak i pozwany. Dla wywołania skutków procesowych zawarcia umowy dowodowej wystarczające jest podniesienie tego zarzutu przez choćby jedną ze stron.

\section{Wymagania co do formy oraz zawarcie umowy pod warunkiem lub z zastrzeżeniem terminu}

Umowę dowodową zawiera się na piśmie pod rygorem nieważności albo ustnie przed sądem (art. $458^{9} \S 2$ zd. 1 k.p.c.). Rozwiązanie to uznać należy za prawidłowe. Służy ono uniknięciu konieczności żmudnego i spornego odtwarzania przed sądem treści umowy dowodowej zawartej bez należytego udokumentowania ${ }^{26}$.

Tak również T. Szancilo, Kodeks..., Komentarz do art. $458^{9}$.

26 Uzasadnienie, s. 107. 
Jeśli umowa zawierana jest na piśmie, to może przybrać formę odrębnej umowy albo klauzuli umownej zawartej w innej umowie. $\mathrm{Z}$ uwagi na brzmienie art. $458^{9}$ $\S 1$ k.p.c. i zawarty w nim warunek, aby umowa taka dotyczyła sprawy wynikającej $\mathrm{z}$ określonego stosunku prawnego powstałego na podstawie umowy, uznać trzeba, że pisemna forma zawarcia umowy dowodowej powinna przeważać w praktyce. Do zawarcia takiej umowy będzie dochodziło najczęściej jeszcze przed powstaniem sporu pomiędzy stronami postępowania gospodarczego. Teza ta wynika z dynamiki konfliktu, który wskazuje, że w sytuacji zaistnienia sporu faktyczna skłonność do jakichkolwiek porozumień pomiędzy stronami drastycznie maleje. Z możliwości zawarcia odrębnej umowy korzystać będą z pewnością częściej te strony, które będą zawierały umowę dowodową już po powstaniu stosunku prawnego wynikającego z umowy, zwykle po powstaniu pomiędzy nimi sporu, ale nie tylko. Aby usunąć jakiekolwiek wątpliwości co do zakresu dokonanych wyłączeń, ustawodawca przewidział, że w przypadku zawarcia kilku umów dowodowych i występowania wątpliwości co do zakresu ich obowiązywania uważa się, że umowa późniejsza utrzymuje w mocy te postanowienia umowy wcześniejszej, które da się z nią pogodzić (art. $458^{9} \S 2$ zd. 2 k.p.c.).

Niedopuszczalne jest także zawarcie umowy dowodowej pod warunkiem lub z zastrzeżeniem terminu. Umowa taka jest w świetle art. $458^{9} \S 3$ k.p.c. nieważna i to w całości ${ }^{27}$. Regulacja ta dotyczy każdego warunku (art. 89-94 k.c.) i terminu (art. 110-116 k.c.) ${ }^{28}$. Zarzut nieważności lub bezskuteczności umowy dowodowej można podnieść najpóźniej na posiedzeniu, na którym powołano się na tę umowę, a jeśli uczyniono to w piśmie procesowym - najpóźniej w następnym piśmie procesowym albo na najbliższym posiedzeniu (§ 4 omawianego przepisu). Słusznie wskazuje się w doktrynie, że w praktyce regulacja ta może być kłopotliwa, jeśli na posiedzeniu obecny jest jedynie pełnomocnik strony, który nie miał świadomości o istnieniu umowy dowodowej i nie jest w stanie ocenić, czy umowa taka jest ważna i skuteczna, czy też nie ${ }^{29}$. Jeśli podniesiono na posiedzeniu zarzut zawarcia umowy dowodowej, a druga strona jest nieobecna na tym posiedzeniu i jest to usprawiedliwiona nieobecność, to należałoby umożliwić tej stronie ustosunkowanie się do tego zarzutu na kolejnym posiedzeniu albo $\mathrm{w}$ piśmie procesowym poprzedzającym to posiedzenie, a sąd powinien ją poinformować o takiej możliwości. Ustawodawca nie uregulował jednak tej kwestii, wobec czego przyjąć należy, że podniesiony przez drugą stronę zarzut

\footnotetext{
Ibidem.

28 Tak słusznie T. Szancilo, op. cit.

29 A. Borys, op. cit., s. 150.
} 
nieważności lub bezskuteczności umowy dowodowej będzie we wskazanej sytuacji sprekludowany. W konsekwencji strona traci w takiej sytuacji prawo powoływania się na te wadliwości ${ }^{30}$. Poza tym nie można zgodzić się ze stanowiskiem, że wadliwość umowy dowodowej może być przedmiotem badania jedynie przed rozpoczęciem czynności w postępowaniu dowodowym ${ }^{31}$. Skoro ustawodawca nie ograniczył możliwości zawarcia umowy przed rozpoczęciem postępowania dowodowego ani też nie wprowadził prekluzji podniesienia faktu zawarcia takiej umowy w postępowaniu cywilnym, to przyjąć trzeba, że również po rozpoczęciu postępowania dowodowego możliwe jest zarówno zawarcie umowy dowodowej, jak również podniesienie tej okoliczności przed sądem, które to może doprowadzić do badania jej ważności i skuteczności w toku postępowania. Podzielić można natomiast stanowisko zakładające, że umowa dowodowa może być nieważna tylko w całości. Jeśli jednak umowa taka była zamieszczona jako klauzula w umowie materialnoprawnej, to zastosowanie co do oceny ważności całej umowy cywilnoprawnej znajdzie art. $58 \S 3$ k.c. ${ }^{32}$

\section{Umowa dowodowa - uproszczenie postępowania czy zagrożenie?}

Biorąc pod uwagę dotychczasowe rozważania, należy uznać, że wprowadzenie do przepisów umowy dowodowej, a także zastosowany przez ustawodawcę sposób jej ukształtowania służy celowi dokonanych zmian w zakresie postępowania gospodarczego. Wyłączenie możliwości skorzystania z określonych środków dowodowych niewątpliwie przyczynia się bowiem do skrócenia czasu potrzebnego do rozstrzygnięcia sporu i sprzyja ekonomii procesowej ${ }^{33}$. Może jednak oddziaływać negatywnie na sprawiedliwość wydawanego w tym postępowaniu rozstrzygnięcia (wówczas, gdy przeprowadzenie wyłączonych umową dowodów doprowadziłoby do innego rozstrzygnięcia, odpowiadającego rzeczywistemu stanowi prawnemu), a także pewność obrotu i sytuację poszczególnych podmiotów postępowania gospodarczego. W tym zakresie dochodzi do poświęcenia takich wartości jak prawda,

30 Osobną kwestią jest natomiast możliwość wzięcia tego faktu pod uwagę z urzędu przez sąd. Zob. szerzej L. Błaszczak, Umowa ..., s. 154.

31 Tak K. Flaga-Gieruszyńska, w: K. Flaga-Gieruszyńska, A. Zieliński, Kodeks postępowania cywilnego. Komentarz, C.H. Beck, Warszawa 2019, Legalis 2019, Komentarz do art. $458^{9}$.

32 Zob. T. Szancilo, op. cit.

33 O tej zalecie umów dowodowych wspominają również R. Kulski, Umowy procesowe w postępowaniu cywilnym (rozważania prawnoporównawcze)..., s. 84; R. Kulski, Umowy procesowe w postępowaniu cywilnym, Zakamycze, Kraków 2006, s. 311-312; R. Morek, I. Szmit, op. cit., s. 223. 
rzetelność czy sprawiedliwość na rzecz szybkiego rozstrzygnięcia sprawy, co może ujemnie wpływać na postrzeganie przez społeczeństwo wymiaru sprawiedliwości. Podkreślał to już W. Mikuszewski, podnosząc, że „w ten sposób sędzia budowałby swój wyrok na karykaturze rzeczywistości i stałby się zabawką w ręku stron. Byłoby to oczywiście sprzeczne z obowiązkami i stanowiskiem sędziego w procesie" ${ }^{34}$. Rozwiązanie to wpływa także na sposób realizacji zasad procesowych ${ }^{35} \mathrm{i}$ umocnienie jednych z nich, kosztem innych. O ile bowiem zwiększona zostaje w ten sposób rola zasad dyspozycyjności ${ }^{36}$ i kontradyktoryjności w postępowaniu cywilnym ${ }^{37}$, o tyle instytucja ta stanowi kolejne odstępstwo od zasady prawdy ${ }^{38}$ i może wpływać na faktyczną równość stron toczącego się postępowania gospodarczego. Poza tym korzyść polegająca na przyspieszeniu rozwiązania spraw in concreto dotyczyć będzie tylko tych przypadków, w których nie doszło do zgłoszenia zarzutów co do samej umowy oraz jej treści. W razie konieczności przesądzenia, czy umowa jest ważna lub skuteczna, zysk czasowy może się okazać iluzoryczny.

Powyższy problem zdaje się zauważać również prawodawca, który eksperymentalnie zdecydował się na wprowadzenie umowy dowodowej jedynie do postępowania gospodarczego, wychodząc z założenia, że w postępowaniu tym występują profesjonaliści, którzy dodatkowo na szeroką skalę korzystają z fachowej pomocy prawnej ${ }^{39}$. Jest to jednak założenie chybione z co najmniej dwóch względów. Po pierwsze, przedsiębiorcy są być może profesjonalistami w swojej dziedzinie, tj. w zakresie prowadzonej działalności gospodarczej, ale nie są z pewnością profesjonalistami w zakresie prawa. Po drugie, ustawodawca nie dokonuje żadnego zróżnicowania pomiędzy podmiotami spraw gospodarczych ze względu na zasięg i rozmiar prowadzonej przez nich działalności. W konsekwencji ta sama regulacja odnosi się zarówno do małych, jednoosobowych przedsiębiorców, jak i do dużych ${ }^{40}$, korzystających z obsługi prawnej, a także - wobec szerokiego rozumienia spraw gospodarczych (zob. art. $458^{2} \S 1$ k.p.c.) - podmiotów niebędących w ogóle przedsiębiorcami. Co więcej, ustawodawca nie bierze pod uwagę faktu, że

M. Mikuszewski, op. cit., s. 228.

Zob. L. Błaszczak, Umowa ..., s. 156-158.

36 Tak również A. Borys, op. cit., s. 144. Zawarcie umowy dowodowej stanowi przejaw dyspozycyjności formalnej (procesowej) dwustronnej, zob. M. Skibińska, w: M. Rzewuski (red.), Postępowanie cywilne, C.H. Beck, Warszawa 2019, s. 39.

37 Zob. Uzasadnienie, s. 106.

38 Odmiennie L. Błaszczak, Problematyka ..., s. 42, ale zob. L. Błaszczak, Umowa..., s. 158. Z kolei A. Borys, op. cit., s. 155, twierdzi, że umowa dowodowa wzmacnia zasadę prawdy formalnej w postępowaniu cywilnym.

39 Uzasadnienie, s. 106. Pogląd ten podziela również A. Borys, op. cit., s. 148.

40 Problem ten zauważa również T. Szancilo, op. cit. 
stronami postępowania gospodarczego, a tym samym również umowy dowodowej mogą być podmioty o różnorodnym statusie i pozycji, zarówno ekonomicznej, jak i prawnej. Typowym przykładem takiej sytuacji może być umowa zawierana przez dewelopera z podwykonawcą prowadzącym jednoosobową działalność gospodarczą albo przez małego, lokalnego dostawcę z siecią super- i hipermarketów. Ponadto istnieje zagrożenie, że przedsiębiorcy, zwłaszcza mali, zawierając tego typu umowy dowodowe, a nawet częściej - godząc się na ich brzmienie zaproponowane przez silniejszego kontrahenta, nie będą zdawali sobie sprawy z konsekwencji dokonywanych czynności. Istnieje co prawda możliwość wzruszenia takiej umowy w oparciu o przepisy k.c., jednakże opcja ta nie zawsze będzie skuteczna, a z pewnością może rodzić trudności dowodowe. Całkowitego zabezpieczenia ich interesów nie daje również możliwość przewidziana w art. $458^{6}$ k.p.c., skoro przepis ten stosuje się wyłącznie na wniosek strony i to tylko wtedy, gdy nie jest ona przedsiębiorcą lub jest przedsiębiorcą będącym osobą fizyczną ${ }^{41}$, choć trzeba uznać, że norma ta chroni przynajmniej częściowo interesy wskazanych w niej podmiotów.

Podsumowując, wprowadzoną regulację w jej obecnym kształcie można w okolicznościach konkretnych spraw uznać za zagrażającą funkcjonowaniu mniejszych przedsiębiorstw w obrocie gospodarczym. Tak surowa ocena nie wypływa z negatywnego nastawienia do samej instytucji umowy dowodowej, ale do sposobu jej uregulowania w obowiązujących przepisach. Na powyższe problemy wskazywano jeszcze przed wprowadzeniem omawianego unormowania do kodeksu. Już wówczas podnoszono, że umowa dowodowa wprawdzie powinna być dopuszczalna, jednakże możliwość jej zawarcia powinna być ograniczona jedynie do okresu po wszczęciu procesu lub przed wszczęciem procesu, jednak nie wcześniej niż w chwili powstania sporu ${ }^{42}$. Stanowisko to nie zostało co prawda uwzględnione w toku prac legislacyjnych, ale wypada się do niego odnieść, choć w kilku argumentach. Przede wszystkim wątpliwym wydaje się, aby po powstaniu sporu, a tym bardziej po wszczęciu procesu dochodziło w ogóle do zawierania umów dowodowych. Jak wskazano, pierwszym elementem takiej umowy jest konsensus stron co do jej zawarcia. Przyjąć trzeba, że powstanie sporu samo w sobie ustawia strony negatywnie względem siebie, co już znacząco osłabia

${ }^{41}$ Odmiennie A. Arkuszewska, która przyjmuje, że wszelkie obawy z tym związane rozwiązuje regulacja art. $458^{6} \S 1$ oraz sposób unormowania umowy dowodowej w k.p.c., w: J. Gołaczyński, D. Szostek (red.), Kodeks postępowania cywilnego. Komentarz do ustawy z 4.7.2019r. o zmianie ustawy - Kodeks postępowania cywilnego oraz niektórych innych ustaw, C.H. Beck, Warszawa 2019, Legalis 2019, Komentarz do art. $458^{9}$.

42 Za: W. Glodowski, op. cit., s. 27. 
zdolność do zawarcia umowy dowodowej. Dynamika konfliktu jeszcze bardziej narasta z chwilą wytoczenia powództwa przed sądem. Szanse na zawarcie umowy dowodowej stają się w tym momencie praktycznie znikome. Dlatego takie unormowanie tego zagadnienia nie byłoby skuteczne, gdyż do zawierania umów dowodowych de facto w ogóle by nie dochodziło albo dochodziłoby bardzo rzadko.

Rozwiązaniem wskazanych problemów nie byłoby również wprowadzenie przymusu adwokacko-radcowskiego do postępowania gospodarczego czy szerzej - postępowania cywilnego przed sądami wszystkich instancji. Przedsiębiorcy mieliby bowiem nadal możliwość zawierania umów dowodowych przed zaistnieniem sporu czy wytoczeniem powództwa, co oznacza, że w większości przypadków pomoc prawna pojawiająca się na etapie postępowania sądowego nie mogłaby już doprowadzić do zmiany sytuacji dowodowej strony. Poza tym także dla adwokatów i radców prawnych instytucja umów dowodowych stanowi nowe wyzwanie i źródło potencjalnych konfliktów z mocodawcą. Sporządzona na niekorzyść umowa dowodowa rodzić może nawet odpowiedzialność cywilnoprawną tych podmiotów względem przedsiębiorcy. $Z$ tych też względów wydaje się, że umowa dowodowa, przynajmniej w początkowym okresie obowiązywania nowej regulacji, będzie stosowana rzadko i to głównie przez dużych przedsiębiorców, korzystających z profesjonalnej obsługi prawnej. Przemawia za tym okoliczność, że jednokrotnie wypracowana i przetestowana klauzula wyłączająca możliwość skorzystania przed sądem z określonych dowodów może być z powodzeniem stosowana przez nich $\mathrm{w}$ standardowych umowach zawieranych $\mathrm{z}$ kontrahentami będącymi również przedsiębiorcami. Tym samym może ona obejmować również osoby niebędące przedsiębiorcami, np. poręczycieli, co jeszcze bardziej uwidacznia dysproporcję pomiędzy podmiotami ewentualnych postępowań sądowych oraz potencjalne źródło nadużyć w wykorzystywaniu umów dowodowych przez silniejsze gospodarczo podmioty.

\section{Zakończenie}

Uchylając w 2011 r. przepisy o postępowaniu odrębnym w sprawach gospodarczych ustawodawca podnosił, że nie można „podzielić zapatrywania, że sprawy gospodarcze powinny być poddane odrębnym rygorom proceduralnym, gdyż występujący w nich przedsiębiorcy jako profesjonaliści w zakresie działalności gospodarczej powinni wykazywać wyższą staranność w prowadzeniu swych spraw, w tym także sądowych, wobec czego można im stawiać w tym względzie wyższe wymagania. Profesjonalizmu w dziedzinie, którą zajmuje się strona 
postępowania, w tym także w dziedzinie działalności gospodarczej, nie należy transponować w sferę postępowania cywilnego, gdyż w tym ostatnim wypadku chodzi jednak o profesjonalizm w zakresie wiedzy prawniczej i jej praktycznego stosowania"43. Obecnie wprowadzona do k.p.c. regulacja przeczy tym słusznym założeniom. Przede wszystkim nie do pogodzenia wydaje się możliwość stosowania tych samych rygorów wobec dużych przedsiębiorców, korzystających z profesjonalnej obsługi prawnej i małych lub średnich przedsiębiorców, którzy w postępowaniu cywilnym (ale również na etapie przedprocesowym) najczęściej występują samodzielnie. Tym bardziej nieodpowiednie wydaje się stosowanie ich w odniesieniu do stron, które nie są przedsiębiorcą. Częściową ochronę zapewnia w tym względzie art. $458^{6}$ $\S 1$ k.p.c., ale chroni on jedynie wąską grupę przedsiębiorców (będących osobami fizycznymi) i osób niebędących przedsiębiorcami. Co więcej, nawet ewentualne wprowadzenie w przyszłości obowiązku zastępstwa procesowego w tym postępowaniu nie wyeliminowałoby wyrażonych powyżej wątpliwości, skoro na etapie zawierania umowy dowodowej strony nie byłyby objęte przymusem adwokacko-radcowskim. Poza tym sytuacja taka w sposób oczywisty podniosłaby koszty funkcjonowania przedsiębiorców w obrocie gospodarczym, negatywnie wpływając na ilość przedsiębiorstw (zwłaszcza jednoosobowych) na rynku. Niesłuszne zdaje się także twierdzenie, że jeśli przedsiębiorcy nie stać na obsługę prawną, to de facto nie powinien prowadzić działalności gospodarczej. Wiele rodzajów działalności opiera się na osobistej pracy przedsiębiorcy (oraz ewentualnie jego rodziny) i jest wystarczające do zapewnienia utrzymania dla niego i jego rodziny. Rozwiązania prawne nie powinny więc eliminować z obrotu prawnego tych przedsiębiorców, ale wspierać ich działalność.

Wprowadzona w postępowaniu gospodarczym instytucja umowy dowodowej nie podlega jednak wyłącznie krytycznej ocenie. Jej nowatorski charakter usprawiedliwia, choćby tylko częściowo, ryzyko negatywnego postrzegania wymiaru sprawiedliwości przez społeczeństwo jako zezwalającego na wydawanie wyroków niezgodnych z rzeczywistością, prawdą czy niesprawiedliwych ${ }^{44}$. Bez podejmowania takiego ryzyka rozwój prawa nie byłby możliwy, a skoro umowa

43 Uzasadnienie projektu ustawy o zmianie ustawy - Kodeks postępowania cywilnego oraz zmianie niektórych innych ustaw Sejmu VI Kadencji, druk nr 4332.

44 Ponadto szybkiego postępowania, nawet z uszczerbkiem dla prawdy materialnej oczekują przedsiębiorcy, tak I. Gil, Pojęcie sprawy gospodarczej i odrębności postępowania w sprawach gospodarczych wedtug projektowanych zmian kodeksu postępowania cywilnego, w: G. Jędrejek, S. Kotas, F. Manikowski (red.), Postępowanie cywilne - wprowadzone i projektowane zmiany 2019, Wolters Kluwer, Warszawa 2019, s. 308. 
dowodowa jest znana innym ustawodawstwom ${ }^{45}$, to warto sprawdzić i zweryfikować możliwość jej funkcjonowania również w naszym systemie prawnym, nawet uwzględniając potencjalne ryzyko, jakie wiąże się z jej zawarciem. Jej wprowadzenie realizuje również zakładany przez ustawodawcę cel, tj. przyspieszenie postępowania gospodarczego ${ }^{46}$, choć - jak wskazano - może się zdarzyć, że $\mathrm{i}$ ta zaleta nie zostanie zrealizowana $\mathrm{w}$ konkretnym postępowaniu (przykładowo z uwagi na konieczność badania ważności i skuteczności umowy dowodowej).

\section{Bibliografia}

\section{Akty prawne}

Ustawa z dnia 23 kwietnia 1964 r. Kodeks cywilny (t.j. Dz.U. z 2019 r., poz. 1145).

Ustawa z dnia 16 listopada 1964 r. Kodeks postępowania cywilnego (t.j. Dz.U. z 2019 r., poz. 1460 ze zm.). Ustawa z dnia 24 października 1989 r. o rozpoznawaniu przez sądy spraw cywilnych (Dz.U. z 1989 r., nr 33, poz. 175 ze zm.).

Ustawa z dnia 16 września 2011 r. o zmianie ustawy - Kodeks postępowania cywilnego oraz niektórych innych ustaw (Dz.U z 2011 r., nr 233, poz. 1381).

Ustawa z dnia 4 lipca 2019 r. o zmianie ustawy - Kodeks postępowania cywilnego oraz niektórych innych ustaw (Dz.U. z 2019 r., poz. 1469).

\section{Opracowania}

Błaszczak Ł., Problematyka umów dowodowych w sądowym postępowaniu cywilnym ze szczególnym uwzględnieniem dowodu z opinii biegłego ad hoc, w: Ł. Błaszczak, K. Markiewicz (red.), Rola biegłego w postepowaniach sądowych, Presscom, Wrocław 2016, s. 15-46.

Blaszczak Ł., Umowa dowodowa jako przyktad nowej instytucji w Kodeksie postępowania cywilnego (art. $458^{9}$ k.p.c.), Palestra 2019/11-12, s. 128-164.

Błaszczak L., Markiewicz K. (red.), Dowody i postepowanie dowodowe w sprawach cywilnych. Komentarz praktyczny z orzecznictwem. Wzory czynności sadowych i procesowych, C.H. Beck, Warszawa 2015.

Borys A., Umowy dowodowe i ich praktyczne wykorzystanie w perspektywie projektowanych zmian kodeksu postępowania cywilnego, w: G. Jędrejek, S. Kotas, F. Manikowski (red.), Postępowanie cywilne - wprowadzone i projektowane zmiany 2019, Wolters Kluwer, Warszawa 2019, s. 142-157.

Dolecki H., Ciężar dowodu w polskim procesie cywilnym, Wydawnictwa Prawnicze PWN, Warszawa 1998.

Flaga-Gieruszyńska K., Zieliński A., Kodeks postępowania cywilnego. Komentarz, C.H. Beck, Warszawa 2019, Legalis 2019.

45 Zob. szerzej R. Kulski, Umowy procesowe w postepowaniu cywilnym (rozważania prawnoporównawcze)..., s. 69-97.

46 Zresztą zamiany służące osiągnięciu tego celu nie dotyczą wyłącznie postępowania dowodowego, zob. np. art. $458^{5}$ i $458^{8} \S 4$ k.p.c. 
Gil I., Pojęcie sprawy gospodarczej i odrębności postępowania w sprawach gospodarczych wedtug projektowanych zmian kodeksu postępowania cywilnego, w: G. Jędrejek, S. Kotas, F. Manikowski (red.), Postepowanie cywilne - wprowadzone i projektowane zmiany 2019, Wolters Kluwer, Warszawa 2019, s. 296-310.

Glodowski W., Odrębności w postępowaniu dowodowym w postępowaniu w sprawach gospodarczych, w: M. Skibińska (red.), Aktualne zagadnienia postępowania dowodowego i środków dowodowych w postępowaniu cywilnym, Acta Iuridica Lebusana, vol. 14, Oficyna Wydawnicza Uniwersytetu Zielonogórskiego, Zielona Góra 2020, s. 21-32.

Gołaczyński J., Szostek D. (red.), Kodeks postępowania cywilnego. Komentarz do ustawy z 4.7.2019 r. o zmianie ustawy - Kodeks postępowania cywilnego oraz niektórych innych ustaw, C.H. Beck, Warszawa 2019, Legalis 2019.

Knoppek K., Recenzja książki „Dowody w postępowaniu cywilnym”, Ł. Błaszczak, K. Markiewicz, E. Rudkowska-Ząbczyk (red.), C.H. Beck, Warszawa 2010, s. XLIV + 672, PPC 2011/2, s. $158-175$.

Kulski R., Odrębności postępowania w sprawach gospodarczych, MoP 2019/21, s. 1166-1175.

Kulski R., Umowy procesowe w postępowaniu cywilnym, Zakamycze, Kraków 2006.

Kulski R., Umowy procesowe w postępowaniu cywilnym (rozważania prawnoporównawcze), w: I. Ratusińska (red.), Czterdziestolecie Kodeksu postępowania cywilnego. Zjazd Katedr Postępowania Cywilnego w Zakopanem (7-9.10.2005), Zakamycze, Warszawa 2006, s. 69-97.

Mikuszewski M., Dopuszczalność umów regulujących sposób prowadzenia dowodów w procesie, Ruch Prawniczy, Ekonomiczny i Socjologiczny 1939/3, s. 226-242.

Morek R., Szmit I., Uwagi o dopuszczalności i skuteczności umów dowodowych w postępowaniach cywilnych i arbitrażowych, w: J. Poczobut, A. Wiśniewski (red.), Prawo prywatne i arbitraż. Księga jubileuszowa dedykowana doktorowi Maciejowi Tomaszewskiemu, Sąd Arbitrażowy przy Krajowej Izbie Gospodarczej w Warszawie, Warszawa 2016, s. 212-223.

Piasecki K., System dowodów i postępowanie dowodowe w sprawach cywilnych, LexisNexis, Warszawa 2010.

Rzewuski M. (red.), Postępowanie cywilne, C.H. Beck, Warszawa 2019.

Skąpski A., Ograniczenia dowodzenia w procesie cywilnym, PWN, Warszawa-Kraków 1981.

Skibińska M., Dowód z zeznań świadka w świetle projektu ustawy o zmianie ustawy - Kodeks postępowania cywilnego oraz niektórych innych ustaw z 8.01.2019 r., w: G. Jędrejek, S. Kotas, F. Manikowski (red.), Postepowanie cywilne - wprowadzone i projektowane zmiany 2019, Wolters Kluwer, Warszawa 2019, s. 119-141.

Szancilo T. (red.), Kodeks postepowania cywilnego. Komentarz. Art. 1-505 ${ }^{39}$, Tom I, C.H. Beck, Warszawa 2019, Legalis 2019.

Zembrzuski T. (red.), Kodeks postępowania cywilnego. Koszty sądowe w sprawach cywilnych. Dochodzenie roszczeń w postępowaniu grupowym. Przepisy przejściowe. Komentarz do zmian, Tom II, Wolters Kluwer, Warszawa 2019.

\section{Inne}

Uzasadnienie projektu ustawy o zmianie ustawy - Kodeks postępowania cywilnego oraz niektórych innych ustaw z dnia 8 stycznia 2019 r., druk nr 3137.

Uzasadnienie projektu ustawy o zmianie ustawy - Kodeks postępowania cywilnego oraz zmianie niektórych innych ustaw, druk Sejmu VI Kadencji, druk nr 4332. 
Magdalena SKIBIŃSKA

\section{SELECTED ISSUES ON EVIDENCE CONTRACTS IN COMMERCIAL CASES PROCEEDINGS}

\section{Abstract}

Background: The subject of this research is the institution of evidence contracts introduced by the amendment of 4.07.2019 to the Polish Code of Civil Procedure in commercial cases proceedings. Research purpose: The first purpose of the paper is to examine the scope of applying the provisions of Article $458^{9}$ and admissible exclusions in the evidence contract. However, the paper also determines the effects of concluding an evidence contract and their potential pros and cons from the perspective of the purpose of the amendment (i.e. speed of proceedings) and certainty in business transactions.

Methods: The formal dogmatic approach was used in the analysis.

Conclusions: The conducted research leads to the conclusion that the introduction of evidence contracts may under certain conditions increase civil justice efficiency. However, this benefit may be illusory in situations requiring examination of the effectiveness and validity of an evidence contract. Furthermore, this institution may also result in abuse of economic power between large entrepreneurs and small enterprises.

Keywords: amendment to the Polish Code of Civil Procedure, efficiency of proceedings, position of small and large entrepreneurs. 